\title{
Improved L-Threonine Production by the Amplification of the Gene Encoding Homoserine Dehydrogenase in Brevibacterium lactofermentum ${ }^{\dagger}$
}

\author{
Shigeru NaKAmori, Masaaki Ishida, Hiroshi TAKagi, \\ Koichi Ito, Kiyoshi Miwa \\ and Konosuke SANO \\ Central Research Laboratories of Ajinomoto Co., Inc., \\ Kawasaki-ku, Kawasaki 210, Japan \\ Received June 11, 1986
}

\begin{abstract}
A $3.2 \mathrm{~kb}$ chromosomal DNA fragment encoding homoserine dehydrogenase (HD) of Brevibacterium lactofermentum M-15, a L-threonine and L-lysine producing mutant, was cloned into the unique PstI site of vector plasmid pAJ1844. Strain M-15 was transformed with the obtained recombinant plasmid pAJ210. The transformant, AJ12021, showed 2-fold higher HD activity and accumulated a 1.4-fold higher amount of $\mathrm{L}$-threonine (maximally $25.0 \mathrm{~g} / \mathrm{liter}$ ) than in the case of the host strain, M-15, respectively. The correlation between the amino acid production and the regulation of enzyme activities was discussed.
\end{abstract}

In Escherichia coli $\mathrm{K}-12$, the improved production of L-threonine, ${ }^{1,2)}$ L-tryptophan ${ }^{3)}$ and L-lysine ${ }^{4)}$ has been achieved by amplifying the genes coding for the corresponding amino acid biosynthetic enzymes using recombinant DNA techniques.

Excellent producers of various amino acids have been obtained through mutation of glutamate producing bacteria such as those belonging to the genera, Brevibacterium and Corynebacterium. ${ }^{5,6)}$ If recombinant DNA techniques are applicable to these bacteria, higher yields of amino acids can be expected.

In Brevibacterium flavum and Brevibacterium lactofermentum, genetically altered HD has been shown to play an essential role in L-threonine production. ${ }^{7 \sim 10}$ ) So, improved L-threonine production would be expected on amplification of the HD gene in these bacteria. Recently, we have constructed a hostvector system for $B$. lactofermentum. ${ }^{11)}$ In this study, using this system, we successfully attempted the amplification of the HD gene of

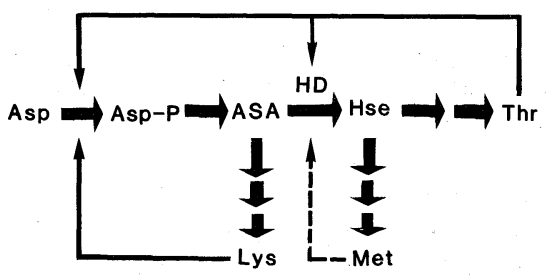

FIG. 1. Pathway and Regulation of L-Threonine Biosynthesis in Brevibacterium lactofermentum.

HD, homoserine dehydrogenase; ASA, aspartate $\beta$-semialdehyde; Hse, homoserine. $\longleftarrow$, feedback inhibition; «-repression.

B. lactofermentum $\mathrm{M}-15$, a $\mathrm{L}$-threonine and $\mathrm{L}-$ lysine producing mutant, ${ }^{10}$ (Fig. 1) and the improvement of L-threonine production.

\section{MATERIALS AND METHODS}

Bacterial strains and a plasmid. Derivatives of B. lactofermentum AJ12036 (wild strain) were used. Strain It-17, a homoserine dehydrogenase deficient mutant, was used as a recipient to clone the HD gene. Strain $\mathrm{M}-15,{ }^{10)}$ a $\mathrm{L}$ threonine and L-lysine producer, selected as a mutant resistant to antimetabolites, $S$-(2-aminoethyl)L-cysteine, $\alpha$ -

$\dagger$ This work was presented in part at the Annual Meeting of the Society of Fermentation Technology, Japan, in Osaka (1983). 
amino- $\beta$-hydroxyvaleric acid and $S$-methylcysteine sulfoxide, and requiring $\mathrm{L}$-isoleucine and L-leucine, was used as a DNA donor and also as a recipient. Two threonine auxotrophs, strain S-2 (a homoserine kinase deficient mutant) and S-7 (a threonine synthase deficient mutant), were used as recipients for the complementation test with a plasmid and as indicators for the halo formation test for $\mathrm{L}$ threonine production. A hybrid plasmid, pAJ1844, ${ }^{11}$, which was constructed by ligating cryptic plasmid, pHM151912) derived from C. glutamicum ATCC13058 and plasmid pBR325 ${ }^{13)}$ from $E$. coli, was used as a vector.

Culture media. CM2G medium, a complete medium, and R3B medium, a regeneration medium for protoplasts, were described in the previous paper. ${ }^{11)} \mathrm{MM}$ medium, which contained $20 \mathrm{~g}$ of glucose, $10 \mathrm{~g}$ of $\left(\mathrm{NH}_{4}\right)_{2} \mathrm{SO}_{4}, 1 \mathrm{~g}$ of $\mathrm{KH}_{2} \mathrm{PO}_{4}, 2.5 \mathrm{~g}$ of urea, $0.4 \mathrm{~g}$ of $\mathrm{MgSO}_{4} \cdot 7 \mathrm{H}_{2} \mathrm{O}, 10 \mathrm{mg}$ of $\mathrm{FeSO}_{4} \cdot 7 \mathrm{H}_{2} \mathrm{O}, 10 \mathrm{mg}$ of $\mathrm{MnSO}_{4} \cdot 4 \mathrm{H}_{2} \mathrm{O}, 50 \mu \mathrm{g}$ of $d$-biotin and $200 \mu \mathrm{g}$ of thiamine $\cdot \mathrm{HCl}$ per liter of distilled water, and adjusted to $\mathrm{pH} 7.0$ with $\mathrm{KOH}$, was used to select transformants. In the case of solid media, $1.5 \%$ agar was added. TP medium for testing L-threonine production was composed of $100 \mathrm{~g}$ of glucose, $45 \mathrm{~g}$ of $\left(\mathrm{NH}_{4}\right)_{2} \mathrm{SO}_{4}, 1 \mathrm{~g}$ of $\mathrm{KH}_{2} \mathrm{PO}_{4}, 0.4 \mathrm{~g}$ of $\mathrm{MgSO}_{4} \cdot 7 \mathrm{H}_{2} \mathrm{O}, 10 \mathrm{mg}$ of $\mathrm{FeSO}_{4} \cdot 7 \mathrm{H}_{2} \mathrm{O}$, $10 \mathrm{mg}$ of $\mathrm{MnSO}_{4} \cdot 4 \mathrm{H}_{2} \mathrm{O}, 300 \mu \mathrm{g}$ of thiamine $\cdot \mathrm{HCl}, 100 \mu \mathrm{g}$ of $d$-biotin, $15 \mathrm{ml}$ of Mieki (hydrolysate of soybean meal) and $50 \mathrm{~g}$ of $\mathrm{CaCO}_{3}$ (sterilized separately) per liter of distilled water, and adjusted to $\mathrm{pH} 7.0$ with $\mathrm{KOH}$. When required, L-leucine $(300 \mu \mathrm{g} / \mathrm{ml})$, L-isoleucine $(250 \mu \mathrm{g} / \mathrm{ml})$ and L-homoserine $(800 \mu \mathrm{g} / \mathrm{ml})$ were added.

Preparation of DNA. Chromosomal DNA of strain M15 was prepared by the modified method of Saito and Miura $^{14)}$ as follows. The strain was cultured in $200 \mathrm{ml}$ of $\mathrm{CM} 2 \mathrm{G}$ medium at $30^{\circ} \mathrm{C}$ for $16 \mathrm{hr}$. The cells were harvested, washed once with saline and then resuspended in $20 \mathrm{ml}$ of TEN buffer (10 mM Tris- $\mathrm{HCl}, 1 \mathrm{~mm}$ EDTA and $5 \mathrm{~mm} \mathrm{NaCl}$, pH 8.0 ) containing $10 \mathrm{mg} / \mathrm{ml}$ of lysozyme. After incubation at $37^{\circ} \mathrm{C}$ for $60 \sim 120 \mathrm{~min}$, sodium dodecyl sulfate was added to a final concentration of $4 \%$ and then the lysate was further incubated at $37^{\circ} \mathrm{C}$ for $60 \mathrm{~min}$. After phenol extraction of the viscous lysate, the crude DNA was treated with preheated RNase and self-digested pronase, followed by a second phenol extraction.

Plasmid DNA was prepared according to the method reported in the previous paper. ${ }^{12)}$

Enzymes for recombinant DNA techniques. The restriction endonucleases, EcoRI, BclI, Pst I and Sst $\mathrm{I}$, and $\mathrm{T}_{4}$ DNA ligase were purchased from New England BioLabs or Bethesda Research Laboratories. Digestion and ligation of DNA were performed according to the manual of Davis et al. ${ }^{15)}$

Protoplast transformation. Preparation of protoplasts, transformation of protoplasts and their regeneration were carried out according to the method of Miwa et al. ${ }^{11)}$

DNA analysis. Electrophoresis was performed in 1.0\% agarose gel with a Tris-acetate buffer system as described by Sharp et al. ${ }^{16)}$ For DNA size determination, bacteriophage $\lambda \mathrm{DNA}$ digested with HindIII and doublestranded $\phi \mathrm{X} 174$ DNA digested with HaeIII were used as molecular weight standards. The plasmid copy number was estimated using cells after cultivation in TP medium at $30^{\circ} \mathrm{C}$ for $24 \mathrm{hr}$ by the method described in the previous paper. ${ }^{12)}$

Selection of $\mathrm{L}-$ threonine producers and their cultivation. For the preliminary selection of $\mathrm{L}$-threonine producers, the halo formation of a L-threonine auxotroph (strain S-2) on MM medium was observed. Selected strains were cultured with shaking in $20 \mathrm{ml}$ of TP medium in flasks at $30^{\circ} \mathrm{C}$ for $72 \mathrm{hr}$. The amounts of L-amino acids were determined by a microbioassay method using Leuconostoc mesenteroides ATCC 8042 or with an amino acid analyser.

Preparation and assay of HD. A crude solution of HD was prepared by the method of Tosaka et al. ${ }^{17)}$ from cells cultured in TP medium at $30^{\circ} \mathrm{C}$ for $24 \mathrm{hr}$. The enzyme activity was determibned according to the method of Truffa-Bachi et al. ${ }^{18)}$

\section{RESULTS}

\section{Cloning of the HD gene}

Chromosomal DNA ( $40 \mu \mathrm{g})$ from strain M15 was partially digested with PstI, and then the resultant fragments were inserted into the PstI site of pAJ1844 $(20 \mu \mathrm{g})$ with $\mathrm{T}_{4}$ DNA ligase. Protoplasts of strain It-17 were transformed with this ligation mixture, and then incubated on R3B agar plates containing $3 \mu \mathrm{g} / \mathrm{ml}$ of chloramphenicol at $30^{\circ} \mathrm{C}$. On incubation for about 10 days, approximately $3 \times 10^{3}$ colonies appeared. One out of these chloramphenicol resistant colonies grew on an MM agar plate containing $10 \mu \mathrm{g} / \mathrm{ml}$ of chloramphenicol. Cloning of the HD gene was confirmed by the high frequency of retransformation of strain It-17 with the obtained recombinant plasmid, pAJ210. No. spontaneous revertant nor chloramphenicol resistant colony was obtained without the addition of pAJ210 DNA. Among ten randomly selected re-transformants, five accumulated about $0.10 \mathrm{~g} /$ liter of L-isolucine and one pro- 
duced $0.10 \mathrm{~g} /$ liter of L-threonine and $0.12 \mathrm{~g} /$ liter of L-isoleucine.

Plasmid pAJ210 does not contain the complete gene encoding homoserine kinase and threonine synthase because it could not complement the threonine auxotrophy of strains $\mathrm{S}$ 2 and $\mathrm{S}-7$.

L-Threonine production by the recombinant strain derived from strain $M-15$

Plasmid pAJ210 was further introduced into strain M-15. From the resultant chloramphenicol resistant colonies, eight better Lthreonine producers than strain M-15 were selected by the halo forming test. The transfor-

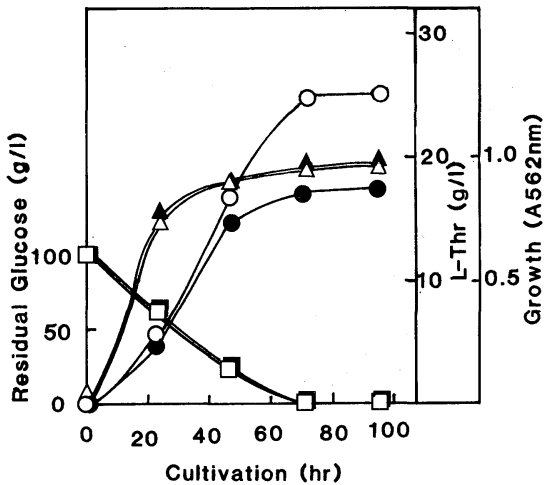

FIG. 2. Time Course of L-Threonine Production by Strains AJ12021 and M-15.

Each strain was cultured at $30^{\circ} \mathrm{C}$ in a flask containing $20 \mathrm{ml}$ of TP medium. $-\triangle-$, growth of AJ12021; $-\mathbf{A}-$, growth of $\mathrm{M}-15 ;-\mathrm{O}-$, threonine production of AJ12021; - - , threonine production of M-15; - $\square-$, residual glucose in broth of $\mathrm{AJ} 12021 ;-\square-$, residual glucose in broth of M-15.

Table I. Production of Amino Acids By Strains M-15 and AJ12021

Strains M-15 and AJ12021 were cultured in TP medium at $30^{\circ} \mathrm{C}$ for $72 \mathrm{hr}$. Amino acid analysis of the culture broth was carried out with an amino acid analyser.

\begin{tabular}{lccc}
\multirow{2}{*}{ Strain } & \multicolumn{3}{c}{ Amino acid produced (g/liter) } \\
\cline { 2 - 4 } & L-Thr & L-Homoserine & L-Lys $\cdot \mathrm{HCl}$ \\
\hline M-15 & 17.5 & 0.5 & 12.1 \\
AJ12021 & 25.0 & 2.8 & 1.1 \\
\hline
\end{tabular}

mants thus selected were cultured in TP medium, and as the best producer, strain AJ12021 was obtained.

Figure 2 shows the time course of L-threonine production by strains AJ12021 and M-15. Strain AJ12021 accumulated $25.0 \mathrm{~g} /$ liter of $\mathrm{L}_{-}$ threonine, i.e., 1.4-fold higher productivity than that of strain $\mathrm{M}-15$, in TP medium on $72 \mathrm{hr}$ cultivation. L-Lysine and L-homoserine as by-products were also determined. As shown in Table I, the amount of L-lysine decreased remarkably whereas that of $\mathrm{L}$ homoserine as well as that of L-threonine increased in the broth of strain AJ12021 as compared with in the case of strain M-15.

\section{Restriction map of $p$ AJ 210}

Plasmid pAJ210 consisted of vector pAJ1844 $(8.8 \mathrm{~kb})$ and a $3.2 \mathrm{~kb}$ chromosomal DNA fragment, which comprised three (1.0, 1.6 and $0.6 \mathrm{~kb})$ Pst I fragments. The relative locations of PstI, EcoRI, SstI and BclI were shown in Fig. 3.

\section{Homoserine dehydrogenase activity}

The HD activity in the crude extract of strain AJ12021 was about 2 times higher than that of strain M-15 (Table II). Feedback inhibition of the enzyme by L-threonine was not observed in either strain AJ12021 or strain M-15.

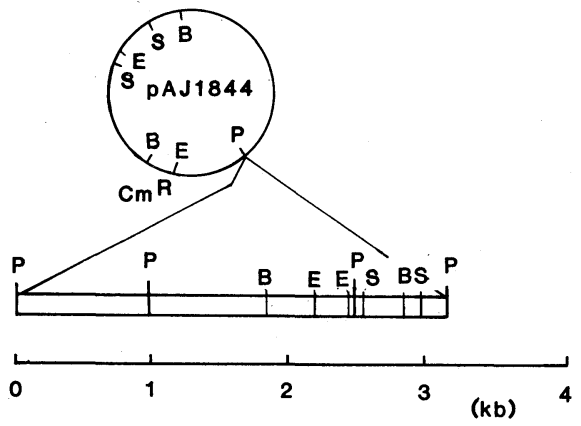

FIG. 3. Restriction Map of pAJ210.

The circle and the straight line indicate vector plasmid pAJ1844 and B. lactofermentum M-15 chromosomal fragment containing the HD gene, respectively. The abbreviations used are: P, PstI ; E, EcoRI; B, BclI ; S, Sst I; $\mathrm{Cm}^{\mathrm{R}}$, chloramphenicol resistance. 
Table II. Comparison of Properties of Homoserine Dehydrogenase from Strains M-15 and AJ12021, and Plasmid Copy Number

Determinations of the HD activity and the plasmid copy number were carried out as described in MATERIALS AND METHODS.

\begin{tabular}{ccc}
\hline Strain & M-15 & AJ12021 \\
\hline Specific activity $^{a}$ & 3.0 & 5.7 \\
\hline Relative activity (\%) & & \\
L-Threonine added (mM) $^{\circ}$ & & \\
0.0 & 100 & 100 \\
0.1 & 100 & 90 \\
1.0 & 96 & 90 \\
10.0 & 94 & 90
\end{tabular}

Plasmid copy number per chromosome ${ }^{b}$ 16

a nmol of NADP reduced $/ \mathrm{min} / \mathrm{mg}$ of protein.

$b$ This estimation is based on the assumption that the molecular size of the M-15 chromosome is the same as that of E. coli.

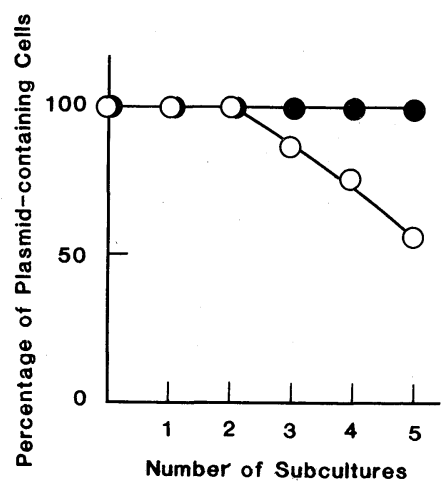

FIG. 4. Stability of pAJ210.

Strain AJ12021 was subcultured repeatedly on CM2G agar plates with chloramphenicol $(10 \mu \mathrm{g} / \mathrm{ml})$ (O) and without chloramphenicol $(\bigcirc)$. After single colony isolation, the drug resistancy of each colony was investigated. About 4.3 cell doublings occurred per subculture.

\section{Stability of hybrid plasmid pAJ 210}

The stability of pAJ210 in strain AJ12021 was determined by checking the frequency of the appearance of chloramphenicol sensitive colonies. Although $45 \%$ of randomly investigated cells had no plasmid after about 20 generations, the addition of $10 \mu \mathrm{g} / \mathrm{ml}$ of chloramphenicol to the CM2G medium prevented clones from curing of pAJ210 (Fig. 4). The improved production of L-threonine on the introduction of pAJ210 was shown by the fact that the productivity of L-threonine by plasmid-cured strains derived from AJ12021 decreased to the level in the case of strain M15.

\section{DISCUSSION}

Potent L-threonine producing mutants of $B$. flavum $^{7,9)}$ and also $B$. lactofermentum ${ }^{10)}$ had been reported. In these mutants, HD had been shown to become genetically insensitive to the feedback inhibition by L-threonine ${ }^{8,10)} \mathrm{B}$. lactofermentum mutant $\mathrm{M}-15^{10)}$ accumulated $\mathrm{L}$ threonine and L-lysine simultaneously owing to the genetic desensitization of aspartokinase to the feedback inhibition by L-threonine plus L-lysine in addition to the desensitization of HD (Fig. 1). The production of L-lysine could be explained by the excess supply of aspartate $\beta$-semialdehyde, a common precursor of $\mathrm{L}$ threonine and L-lysine, due to the relatively higher activity of aspartokinase than that of HD. Therefore, an increase in L-threonine and a decrease in L-lysine could be expected on further elevation of the HD activity.

Using a novel host-vector system constructed in B. lactofermentum, ${ }^{11}$ a $3.2 \mathrm{~kb}$ DNA fragment encoding HD from strain M-15 has been cloned into the Pst I site of vector plasmid pAJ1844. Introduction of the recombinant plasmid pAJ210 thus obtained into strain M15 resulted in increases in L-threonine and $\mathrm{L}_{-}$ homoserine productions and a decrease in Llysine production, as had been expected (Table I). For preliminary analysis of the gene structure, the HD gene was subcloned into a $2.6 \mathrm{~kb}$ PstI DNA fragment $(1.0 \mathrm{~kb}$ and $1.6 \mathrm{~kb}$ fragments) derived from the $3.2 \mathrm{~kb}$ PstI DNA fragment using vector pAJ226 ${ }^{19}$ (unpublished data). The promoter like sequence, which is used for read-through transcription, is not found near the PstI cloning site of pAJ226. So, this suggests that the HD gene containing the original promoter bestrides the $1.0 \mathrm{~kb}$ and $1.6 \mathrm{~kb}$ PstI DNA fragments. 
The copy number of pAJ210 was about 16 . The enzyme activity was rather low as compared with the copy number (Table II). Expression of the HD gene on the plasmid may be restricted, and thus further improvement would be necessary. And at the same time, we expected that amplification of other $\mathrm{L}_{-}$ threonine biosynthetic enzymes, i.e., homoserine kinase and threonine synthase, would be effective for the further improvement of $\mathrm{L}$ threonine production, and so continuous studies are being carried out.

Acknowledgments. We are indebted to Dr. Akashi, Dr. Okada, Mr. Miyamae, Mr. Tahara and Dr. Tsugawa of our laboratories for their encouragement.

\section{REFERENCES}

1) K. Miwa, T. Tsuchida, O. Kurahashi, S. Nakamori, K. Sano and H. Momose, Agric. Biol. Chem., 47, 2329 (1983).

2) V. G. Debabov, Abstracts of Papers, the FEMS Symposium on Overproduction of Microbial Products, Hradec, Kralove, Czechoslovakia, 1981.

3) S. Aiba, T. Imanaka and H. Tsunekawa, Biotech. Lett., 2, 525 (1982).

4) B. Dauce-Le Reverend, M. Boitel, A. M. Deschamps, J. M. Lebeaut, K. Sano, K. Takinami and J. C. Patte, Eur. J. Appl. Microbiol. Biotechnol., 15, 227 (1982).

5) "Microbial Production of Amino Acids," ed. by K. Yamada, S. Kinoshita, T. Tsunoda and K. Aida,
Kodansha, Tokyo, 1972.

6) F. Yoshinaga and S. Nakamori, "Amino Acids: Biosynthesis and Genetic Regulation," ed. by K. M. Hermann and R. L. Somerville, Addison-Wesley Publishing Co., Reading, Massachusetts, 1983, p. 405.

7) I. Shiio and S. Nakamori, Agric. Biol. Chem., 34, 448 (1970).

8) I. Shiio, R. Miyajima and S. Nakamori, J. Biochem., 68, 859 (1970).

9) S. Nakamori and I. Shiio, Agric. Biol. Chem., 37, 653 (1973).

10) O. Tosaka, M. Ishihara, Y. Morinaga and K. Takinami, Agric. Biol. Chem., 43, 265 (1979).

11) K. Miwa, K. Matsui, M. Terabe, K. Ito, M. Ishida, H. Takagi, S. Nakamori and K. Sano, Gene, 39, 281 (1985).

12) K. Miwa, H. Matsui, M. Terabe, S. Nakamori, K. Sano and H. Momose, Agric. Biol. Chem., 48, 2901 (1984).

13) F. Bolivar, Gene, 4, 121 (1978).

14) H. Saito and K. Miura, Biochim. Biophys. Acta, 72, 619 (1963).

15) "Advanced Bacterial Genetics. A Manual for Genetic Engineering," ed. by R. W. Davis, D. Botstein and J. R. Roth, Cold Spring Harbor Laboratory, Cold Spring Harbor, New York, 1980.

16) P. A. Sharp, B. Sugden and J. F. Sambrook, Biochemistry, 12, 3055 (1973).

17) O. Tosaka and K. Takinami, Agric. Biol. Chem., 42, 95 (1978).

18) P. Truffa-Bachi, G. LeBras and G. N. Cohen, Biochim. Biophys. Acta, 128, 450 (1966).

19) H. Takagi, Y. Morinaga, K. Miwa, S. Nakamori and K. Sano, Agric. Biol. Chem., 50, 2597 (1986). 